Vol. 6(4), pp. 46-54,April, 2014

DOI: $10.5897 /$ J JFA2013.0397

Article Number:DF9 115 E44221

ISSN 2006-9839

Copyright (C2014

Author(s) retain the copyright of this article

http://www.academicjournals.org/ijfa
International Journal of Fisheries and

Aquaculture

Full Length Research Paper

\title{
Diet composition, ontogenetic dietary shifts and morphometric relationships of the Nile barb Barbus bynni (Forsskål, 1775) (Pisces: Cyprinidae) in Lake Abaya, Ethiopia
}

\author{
Elias Dadebo ${ }^{1 *}$, Seble Bancha ${ }^{2}$, Abinet Wolde-Senbet ${ }^{2}$ and Yosef Teklegiorgis $^{3}$ \\ ${ }^{1}$ Department of Biology, Hawassa University, P. O. Box 5, Hawassa, Ethiopia. \\ ${ }^{2}$ Department of Biology, Wolaita Sodo University, P. O. Box 138, Wolaita Sodo, Ethiopia. \\ ${ }^{3}$ Department of Animal and Range Sciences, Hawassa University, P. O. Box 336, Hawassa, Ethiopia.
}

Received 7 November, 2013; Accepted 7 April, 2014

\begin{abstract}
Food and feeding habits of Barbus bynni (Forsskål, 1775) were studied in Lake Abaya, Ethiopia, from January to February, 2010 (dry season) and May to June, 2010 (wet season). From a total of 292 fish samples, $251(86.0 \%)$ contained food in their guts. Macrophytes, insects and detritus were the dominant food categories both during the dry and wet seasons. Macrophytes and detritus occurred in 78.1 and $73.3 \%$ of the guts, and constituted 30.4 and $29.3 \%$ of the total food volume, respectively while insects occurred in $72.5 \%$ of the guts and accounted for $29.2 \%$ of the total volume. Zooplankton occurred in $37.5 \%$ of the guts but they constituted only $4.6 \%$ of the total volume of food categories. No seasonality in diet was observed, however, there was an ontogenetic change in diet. In juveniles, the contribution of food of animal origin was relatively high, whereas in adults the contribution of plant materials was dominating. The relationships between total length (TL) and total weight (TW) of males, females and both sexes combined were curvilinear and statistically significant $(P<0.001)$. The relationships between $T L$ and fork length (FL), TL and standard length (SL) and FL and SL were all linear and statistically significant $(P<0.001)$. The growth pattern of $B$. bynni in Lake Abaya was allometric because the slope of the relationship (b) was 3.25 , which is a value considerably higher than 3 .
\end{abstract}

Key words: Barbus bynni, diet composition, feeding habits, Lake Abaya, morphometric relationships.

\section{INTRODUCTION}

The Nile barb Barbus bynni (Forsskål, 1775) is a benthopelagic freshwater fish widely distributed in the Nile system and in lakes that were once connected to the Nile (Golubtsov and Krysanov, 1993; Bailey, 1994). In Ethiopia, the species is widely distributed in the Southern

Rift Valley Lakes, Abaya and Chamo, the

*Corresponding author. E-mail: edadebo@yahoo.com

Author(s) agree that this article remain permanently open access under the terms of the Creative Commons Attribution License 4.0 International License 


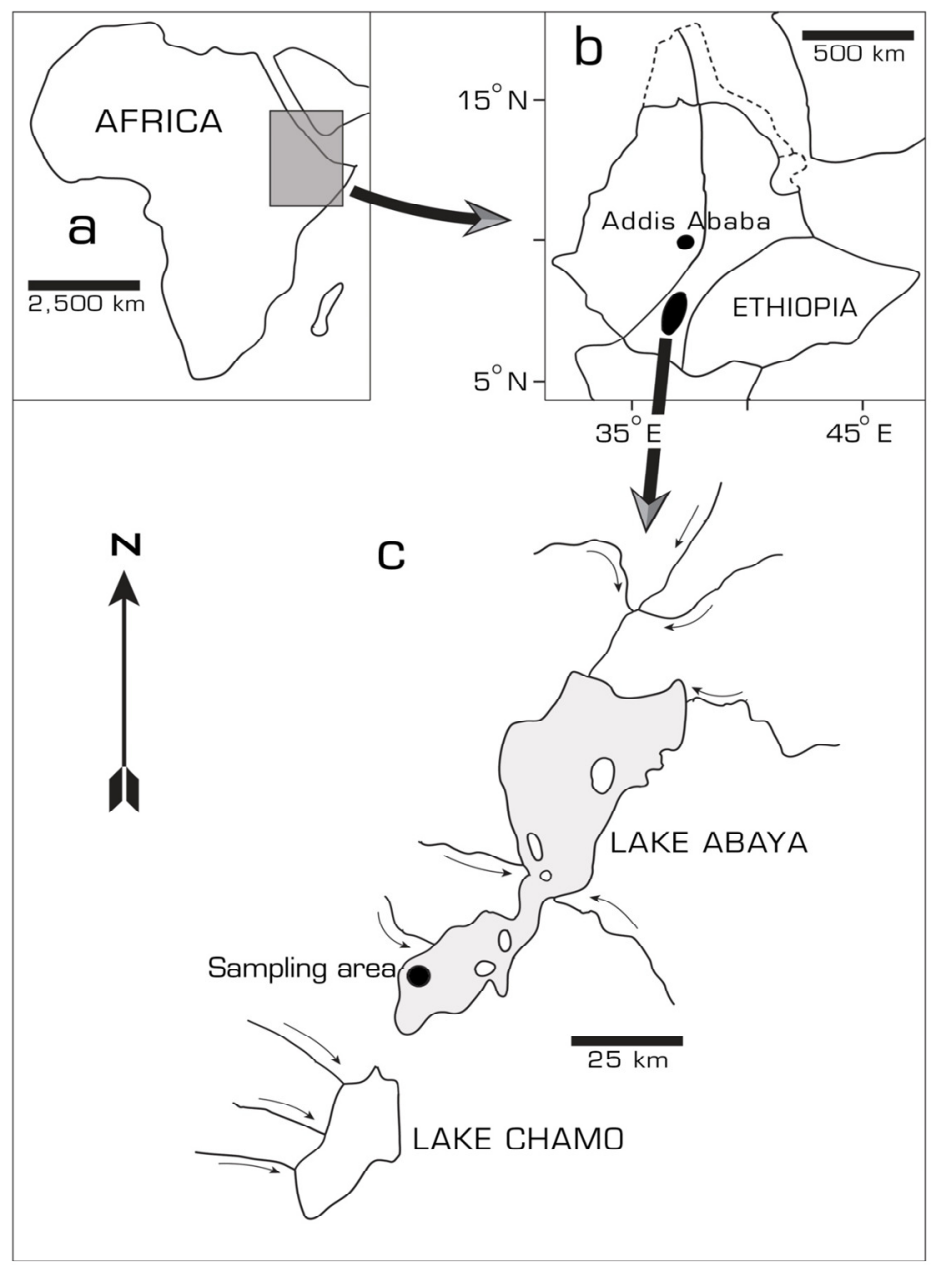

Figure 1. Map of Africa with horn of Africa region highlighted (a), map of Ethiopia with the southern rift valley lakes area indicated (b), maps of Lakes Abaya and Chamo with the sampling area in Lake Abaya shown (c).

Omo River and the rivers that drain into the Nile system (Golubtsov et al., 1995; Getahun, 2007; Golubtsov and Habteselassie, 2010).

African barbs belong to the genus Barbus and are divided into small and large barbs. The division is supported by cytogenetics, the smaller barbs having 50 chromosomes while the large barbs have 150 (Berrebi and Valiushok, 1998). B. bynni belongs to the large Barbus group sensu (Banister, 1973).

Although $B$. bynni is commercially important in Lake Abaya, no study has been conducted on the biology and ecology of the species. No published information is available on the food and feeding habits and morphometric relationships of $B$. bynni in African water bodies in general and in Lake Abaya in particular.

The aim of this work was, therefore, 1 ) to investigate the food and feeding habits of B. bynni in Lake Abaya, and 2) to provide basic information on morphometric relationships of this species in Lake Abaya.

\section{MATERIALS AND METHODS}

\section{Study area}

Lake Abaya (Latitude: 5³0' - 6³0' N and Longitude: 36³0’ $\left.38^{\circ} 30^{\prime} \mathrm{E}\right)$ is the largest Ethiopian Rift Valley Lake located in the southern part of the Ethiopian Rift Valley, east of the Guge Mountains, at an elevation of 1,285 m (Figure 1). The Bilate River that rises from the southern slope of the Gurage Mountains is the major influent of the lake (Baxter, 2002). The town of Arbaminch lies on its southwestern shore. The lake has a maximum length of $60 \mathrm{~km}$, width of $20 \mathrm{~km}$, and a catchment area of $17,300 \mathrm{~km}^{2}$ (Tudorancea et al., 1999). The surface area of the lake is 1,162 $\mathrm{km}^{2}$, with a maximum depth of $13 \mathrm{~m}$ (Baxter, 2002).

There are a number of islands in this lake, the largest being Aruro; 
others include Gidicho, Welege, Galmaka, and Alkal. The lake is reddish in color due to high load of suspended clay particles. Lake Abaya does not always have an outflow, but in some years, it overflows into Lake Chamo. Nech Sar National Park, known for its wild life and bird life surrounds the lake, which is also fished by local people. The ichthyo-fauna of Lake Abaya, and also that of the neighbouring Lake Chamo, is Soudanian species (Beadle, 1981). The fish species are more diverse than that of the other rift valley lakes of the country probably due to a previous inter-connection of Lakes Abaya, Chamo, Chew Bahir and Turkana with the Nile system (Beadle, 1981). There are 21 fish species found in Lakes Abaya and Chamo and the inflowing rivers (Golubtsov and Habteselassie, 2010). The commercially important species are Oreochromis niloticus (Linnaeus, 1758), Labeo horie (Heckel, 1847), Bagrus docmak (Forsskål, 1775), Clarias gariepinus (Burchell, 1802) and Lates niloticus (Linnaeus, 1758).

According to Tudorancea et al. (1999), the lake has a secchi disc depth of $19 \mathrm{~cm}$ and a $\mathrm{pH}$ of 8.7 with conductivity $\left(\mathrm{K}_{25}\right)$ of 800 $\mu \mathrm{S} / \mathrm{cm}$. The area in which the lake lies is mainly volcanic in origin while the waters of the lake are permanently turbid due to heavy colloidal suspension of ferric oxide and the high turbidity of the lake greatly reduces primary productivity and fish production (Schröder, 1984).

\section{Fish sampling and measurements}

Sampling was done four times, twice during the dry season (January and February) and twice during wet season (May and June). In the shallow littoral area, a beach seine $(25 \mathrm{~m}$ long and 3 $\mathrm{m}$ wide with a mesh size of $0.6 \mathrm{~cm}$ ) was used for sampling, while Nordic survey multi-mesh monofilament nylon gillnets (Appelberg et al., 1995) were used in the pelagic area of the lake (Figure 1). The multi-mesh gillnets consisted of twelve randomly distributed panels of the mesh sizes $5,6.25,8,10,12.5,15.5,19.5,25,29,35,43$, and $53 \mathrm{~mm}$ (bar mesh). Each panel was $2.5 \mathrm{~m}$ long, and hence the total length (TL) of each net was $30 \mathrm{~m}$. The nets were $1.5 \mathrm{~m}$ deep with a total area of $45 \mathrm{~m}^{2}$. The depth of the water where the gillnets were set ranged between 3 to $5 \mathrm{~m}$ about $1.5 \mathrm{~km}$ inward from the littoral sampling station. They were set around 7.00 am and pulled around $3.00 \mathrm{pm}$. A total of 292 fish were collected. Fish were then removed from the gillnets shortly after landing. The TL, fork length $(F L)$ and standard length (SL) were measured to the nearest $\mathrm{mm}$, while total weight (TW) was measured to the nearest gram.

\section{Food and feeding}

Since $B$. bynni has no distinct stomach, contents of the entire gut were taken and preserved in 5\% formalin immediately after morphometric measurements were taken. The gut contents were examined and prey items identified under a dissecting microscope (LEICA MS5, magnification 40x) and compound microscope (LEICA DME, magnification 100x), in the Biology Laboratory at Hawassa University. The relative importance of food items was determined using the following methods:

\section{Frequency of occurrence}

The number of gut samples containing one or more of a given food items was expressed as a percentage of all non-empty guts examined (Bagenal and Braum, 1978). The proportion of the population that feeds on certain food items was estimated by this method.

\section{Volumetric analysis}

Food items that were found in the guts were sorted into different food categories, and the water displaced by a group of items in each category was measured in a partially filled graduated cylinder (Bowen, 1983). The volume of water displaced by each category of food item was expressed as a percentage of the total volume of the gut contents (Bowen, 1983). The importance of different food categories was determined by categorizing the TL of the fish into four size classes (I: 10.0 to $19.9 \mathrm{~cm}$, II: 20.0 to $29.9 \mathrm{~cm}$, III: 30.0 to $39.9 \mathrm{~cm}$ and IV: 40.0 to $49.9 \mathrm{~cm}$ ) and the total volume of food in each size class was determined. The volumetric contribution of each of food category was then expressed as a percentage of the total volume of food consumed in each size class.

\section{Statistical analysis}

Chi-square test was used to compare frequency of occurrences of the different food categories during the dry and wet seasons (Sokal and Rohlf, 1995). Similarly, the non-parametric Mann-Whitney's U test was used to compare the volume of the different food categories consumed during the dry and wet seasons since the data did not satisfy the assumption of equal variance to employ a parametric test.

Dietary overlap between different length-classes was calculated using Schoener Diet Overlap Index (SDOI) (Schoener, 1970; Wallace, 1981):

$$
\alpha=1-0.5\left(\Sigma_{i=1}^{n}|p x i-p y i|\right)
$$

Where $\alpha$ is percentage overlap, SDOI, between length classes $x$ and $y, p x i$ and pyi are proportions of food category (type) $i$ used by $x$ and $y$, and $n$ is the total number of food categories. Overlap in the index is generally considered to be biologically significant when $a$ value exceeds 0.60 (Mathur, 1977).

\section{Morphometric relationships}

Length-weight relationship was calculated using the following formula:

$$
\mathrm{TW}=\mathrm{aTL} \mathrm{L}^{\mathrm{b}}
$$

Where TW is total weight $(\mathrm{g})$, TL is total length $(\mathrm{cm})$, and $a$ and $b$ are intercept and slope of the length-weight regression equation, respectively.

A linear relationship was used to determine the relationships between TL and FL, TL and SL and FL and SL.

\section{RESULTS AND DISCUSSION}

\section{Diet composition}

B. bynni ranging from 11.6 to $50.0 \mathrm{~cm} \mathrm{TL}$ and 14.2 to $1,200 \mathrm{~g}$ TW were considered for food and feeding habit study. The longest female in the sample was $50 \mathrm{~cm} T L$ and $1,200 \mathrm{~g} \mathrm{TW}$, whereas the longest male fish was 35.8 $\mathrm{cm} \mathrm{TL}$ and $359.2 \mathrm{~g} \mathrm{TW}$. The size frequency distribution of the fish during both dry and wet seasons is given in 


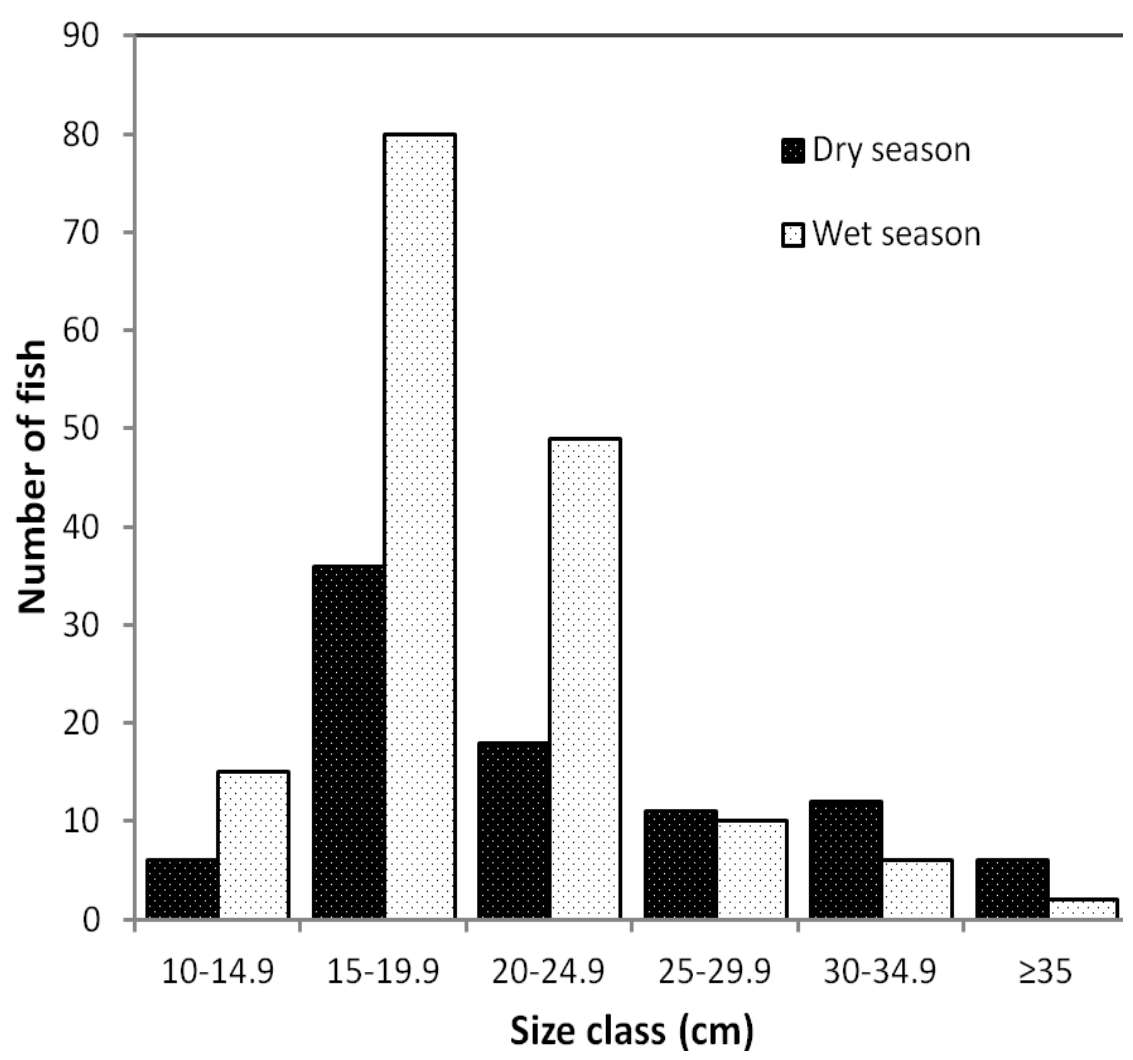

Figure 2. Size frequency distribution of $B$. bynni during the dry $(n=89)$ and wet $(n=$ 162) seasons in Lake Abaya.

Figure 2. Out of the total number of 292 examined fish, $41(14 \%)$ had empty guts. The food categories found in the guts of 251 individuals of $B$. bynni included macrophytes, detritus, insects, zooplankton, phytoplankton, ostracods, gastropods and nematodes (Table 1). Macrophytes, detritus and insects were the most important food categories of $B$. bynni in Lake Abaya. Zooplankton were also encountered relatively frequently, while the remaining food categories (ostracods, nematodes, gastropods and phytoplankton) occurred in few guts (Table 1).

Macrophytes occurred in $78.1 \%$ of the examined guts and volumetrically they accounted for $30.4 \%$ of the total food volume (Table 1). Detritus occurred in $73.3 \%$ of the guts and accounted for $29.2 \%$ of the total volume, while insects occurred in $72.5 \%$ of the guts and accounted for $29.1 \%$ of the total volume. The digestibility of plant food categories could be an important factor in their relatively higher volume, because food of plant origin may resist digestion while soft bodied invertebrates and zooplankton may be lost quickly due to digestive processes. Zooplankton occurred in relatively high number of guts $(37.5 \%)$, but their volumetric contribution was small $(4.6 \%)$. Nematodes, ostracods, gastropods and phytoplankton occurred in 4.0 to $21.5 \%$ of the guts and collectively accounted for only $6.5 \%$ of the total food volume (Table 1). Among the three zooplankton groups identified in the guts of $B$. bynni, Daphnia sp. occurred in $19.9 \%$, and accounted for $3.2 \%$ of the total volume, followed by Cerriodaphnia sp. and rotifers that occurred in 10 and $9.2 \%$, and constituted 0.6 and $0.7 \%$ of the total food volume, respectively. Among the insects, Chironomidae larvae occurred in $43.0 \%$ of the guts and accounted for $11.3 \%$ of the total volume, followed by Ephemeroptera occurring in $22.3 \%$ and constituting $9.3 \%$ of the total volume (Table 1). Coleoptera and Plecoptera were also relatively important food items, occurring in 25.1 and $22.7 \%$ of the guts respectively and accounting for 3.5 and $3.3 \%$ of the total volume, respectively. The remaining insects were of minor importance, with occurrence in few guts, and with low contribution to the total gut content. Among the three phytoplankton categories identified, diatoms accounted for $1.1 \%$, followed by blue green algae $(0.7 \%)$, and green algae $(0.4 \%)$ by volume.

Apparently, there are very few studies done concerning the food and feeding habits of $B$. bynni. Froese and Pauly(2010) have reported that three sub-species of $B$. bynni: B. bynni bynni, Barbus bynni occidentalis and $B$. 
Table 1. Frequency of occurrence and volumetric contribution of food items consumed by $B$. bynni in Lake Abaya $(\mathrm{n}=251)$.

\begin{tabular}{lcccc}
\hline \multirow{2}{*}{ Food item } & \multicolumn{2}{c}{ Frequency of occurrence } & \multicolumn{2}{c}{ Volumetric contribution } \\
\cline { 2 - 5 } & Frequency & Percent & Volume (mI) & Percent \\
\hline Macrophytes & 196 & 78.1 & 28.5 & 30.4 \\
Detritus & 184 & 73.3 & 27.4 & 29.2 \\
Insects & & & & \\
Chironomid larvae & 182 & 72.5 & 27.3 & 29.1 \\
Ephemeroptera & 108 & 43.0 & 10.5 & 11.2 \\
Coleoptera & 56 & 22.3 & 8.7 & 9.3 \\
Plecoptera & 63 & 25.1 & 3.3 & 3.5 \\
Diptera & 57 & 22.7 & 3.1 & 3.3 \\
Hymnoptera & 33 & 13.1 & 0.6 & 0.6 \\
Chironomid pupa & 5 & 2.0 & 0.5 & 0.5 \\
Anisoptera & 5 & 2.0 & 0.4 & 0.4 \\
& 6 & 2.4 & 0.2 & 0.2 \\
Zooplankton & & & & \\
Daphnia & 94 & 37.5 & 4.3 & 3.6 \\
Ceriodaphnia & 50 & 19.9 & 3.0 & 0.6 \\
Rotifers & 25 & 10.0 & 0.6 & 0.7 \\
& 23 & 9.2 & 0.7 & 2.2 \\
Phytoplankton & & & & 0.7 \\
Blue green algae & 31 & 12.4 & 2.1 & 0.4 \\
Green algae & 15 & 6.0 & 0.7 & \\
Diatoms & 4 & 1.6 & 0.4 & 2.1 \\
& 12 & 4.8 & 1.0 & 1.5 \\
Ostracods & & & & 0.7 \\
Gastropods & 54 & 21.5 & 2.0 & \\
Nematodes & 10 & 4.0 & 1.4 & 0.7 \\
\hline
\end{tabular}

Note that the percentage volume of the major food categories in bold adds up to $100 \%$.

bynni waldroni feed on almost the same types of food items despite the difference in their distribution. B. bynni bynni is distributed in the Nile system, in Egypt, Ethiopia, Kenya and Sudan (Lévêque and Daget, 1984; Bailey, 1994; Seegers et al., 2003; Getahun, 2007). This subspecies feeds on detritus, zoobenthos, crustaceans, insects and gastropods. The above feeding habit of $B$. bynni bynni agrees well with the results of the present study, but unlike many other studies on other Barbus species in Ethiopia, no piscivorous individuals were encountered in B. bynni from Lake Abaya. Admassu and Dadebo (1997) studied the feeding habits of Barbus sp. in Lake Hawassa and reported that the species is polyphagous, but according to these authors, the species tended to become piscivorous above $30 \mathrm{~cm}$ TL. Nagelkerke et al. (1994) studied the barbs of Lake Tana and reported that 8 out of 15 species were piscivorous, while the remaining 7 species were benthivorous and polyphagous. Likewise, the polyphagous feeding habit of Barbus species was reported by several authors from different fresh waters of the world.

De Graaf (2003) conducted a detailed study on the feeding habits of piscivorous barbs and found a high degree of piscivory even though piscivory is rare in cyprinids due to lack of teeth, stomach and the associated digestive enzymes (de Graaf et al., 2010). In the absence of specialized piscivores many Barbus species may consume relatively large proportions of fish prey, especially at later stages during their ontogeny. Desta et al. (2006) suggested at least two feeding forms of Lasiurus intermedius in Lake Hawassa, Ethiopia: those that prey up on fish, and those that are polyphagous. In another extensive study on the feeding habits of a small barb, Barbus paludinosus, Desta et al. (2008) reported ostracods, zooplankton, mollusks, aquatic insects and fish to be the most important food categories.

\section{Seasonal variation in the diet}

The frequency of occurrence of zooplankton and phytoplankton in the diet significantly varied during the dry $(n=89)$ and wet $(n=162)$ seasons $(P<0.05)$. Similarly, the volumetric contribution of ostracods significantly differed during the two seasons $(P<0.05)$. On the other hand, both frequency and volumetric contributions of all other food items did not significantly differ during the two seasons (Table 2). Among the three 
Table 2. Relative contribution of different food items in the diet of $B$. bynni during the dry $(\mathrm{n}=89)$ and wet $(\mathrm{n}$ $=162$ ) seasons.

\begin{tabular}{lcccc}
\hline \multirow{2}{*}{ Food item } & * & \multicolumn{2}{c}{ Frequency of occurrence (\%) } & \multicolumn{2}{c}{ Volumetric contribution (\%) } \\
\cline { 2 - 5 } & Dry season & Wet season & Dry season & Wet season \\
\hline Detritus & $72.5^{\mathrm{a}}$ & $73.5^{\mathrm{a}}$ & $31.7^{\mathrm{a}}$ & $24.6^{\mathrm{a}}$ \\
Macrophytes & $84.3^{\mathrm{a}}$ & $76.5^{\mathrm{a}}$ & $30.1^{\mathrm{a}}$ & $30.8^{\mathrm{a}}$ \\
& & & & \\
Zooplankton & $27.5^{\mathrm{a}}$ & $39^{\mathrm{b}}$ & $3.7^{\mathrm{a}}$ & $6.3^{\mathrm{a}}$ \\
Rotifers & 9.8 & 9 & 0.3 & 1.5 \\
Cereodaphnia & 9.8 & 10 & 0.5 & 1.0 \\
Daphnia & 9.8 & 22.5 & 2.9 & 3.7 \\
Insects & & & & \\
Chironomidae larvae & $78.4^{\mathrm{a}}$ & $71^{\mathrm{a}}$ & $29.8^{\mathrm{a}}$ & $28.1^{\mathrm{a}}$ \\
Chironomidae pupa & 68.6 & 36.5 & 13.9 & 6.2 \\
Diptera & 2.0 & 2 & 0.1 & 1.1 \\
Plecoptera & - & 16.5 & - & 2.0 \\
Coleoptera & 9.8 & 26 & 1.5 & 6.7 \\
Ephemeroptera & 15.7 & 27.5 & 2.5 & 5.5 \\
Anisoptera & 31.4 & 20 & 11.0 & 6.0 \\
Hymnoptera & 2.0 & 2.5 & 0.2 & 0.1 \\
Phytoplankton & 2.0 & 2 & 0.5 & 0.5 \\
Blue green algae & & & & \\
Green algae & $31.4^{\mathrm{b}}$ & $7.5^{\mathrm{a}}$ & $2.2^{\mathrm{a}}$ & $2.3^{\mathrm{a}}$ \\
Diatom & 21.6 & 2 & 1.2 & 0.1 \\
& 3.9 & 1 & 0.5 & 0.1 \\
Ostracods & 5.9 & 4.5 & 0.6 & 2.1 \\
Gastropods & & & & \\
Nematodes & $17.6^{\mathrm{a}}$ & $22.5^{\mathrm{a}}$ & $0.7^{\mathrm{a}}$ & $4.7^{\mathrm{b}}$ \\
\hline
\end{tabular}

Note that the volume of the major food categories in bold adds up to $100 \%$. *Values of respective food categories under the same category given different superscript letters are significantly different $(\alpha<0.05)$.

major food categories of $B$. bynni, detritus composed slightly higher volume during the dry season (31.7\%) than in the wet season (26.4\%). The contribution of macrophytes in the diet during the dry and the wet seasons (30.1 and $30.9 \%$, respectively) and insects ( 29.7 and $28.1 \%$, respectively) was fairly comparable (Table 2 ). Also, the overall volume of phytoplankton in the guts was comparable during the dry (2.2\%) and wet (2.3\%) seasons. The importance of zooplankton in the diet increased during the wet season (6.3\%) compared to the dry season (3.7\%). Similarly, ostracods and nematodes were consumed considerably more during the wet season than in the dry season, while gastropod consumption remained fairly constant during the two seasons (Table 2).

Although the total volume of insects in the diet remained similar during the dry and wet seasons, the contribution of the different taxa considerably varied during the two periods (Table 2). During the dry season, Chironomidae larvae and Ephemeroptera composed most of the insect bulk consumed by $B$. bynni in Lake Abaya (13.9 and $11.0 \%$, respectively). Whereas their contribution dropped by about $50 \%$ in the wet season
( 6.2 and $6 \%$ by volume, respectively).

On the other hand, the contribution of Plecoptera increased from 1.5 to $6.7 \%$ by volume, and that of Coleoptera increased from 2.5 to $5.5 \%$ by volume during the wet season compared to the dry season (Table 2). Comparing the two seasons, $B$. bynni consumed a fairly diverse group of insects during the wet season, whereas only two insect taxa composed most of the insect bulk consumed during the dry season.

Among zooplankton, Daphnia sp. was the most important during both seasons, but its contribution increased in the wet season than in the dry season. Also, the significance of the other two less important zooplankton (rotifers and Cerriodaphnia sp.) relatively increased in the wet season than in the dry season. Considering phytoplankton taxa, diatoms made up nearly all algal volume eaten during the wet season whereas, blue greens together with some greens and diatoms shared the dry season algae diet (Table 2).

The results of the present study have shown no significant difference on the feeding habits of $B$. bynni during the dry and wet seasons although there were some variations in the proportion of certain food 
categories during the two seasons. The proportions of macrophytes, zooplankton, ostracods and nematodes were higher during the wet season while the proportions of detritus, insects, phytoplankton and gastropods were higher during the dry season. This difference in the proportions of the different food categories could be due to the difference in the availability and emergence of various food items during dry and wet seasons. Kolding (1989) observed seasonal migration of B. bynni from inshore areas to offshore habitats in Lake Turkana (Kenya). According to this author, during the wet season with high turbidity the population tends to migrate to inshore areas with progressive offshore movement as the water clears during the dry season (Kolding, 1989). Admassu and Dadebo (1997) studying Barbus sp. in Lake Hawassa (Ethiopia) and Dadebo et al. (2013) working on L. intermedius in Lake Koka (Ethiopia) reported seasonal variation in the diet of the studied fish species. The present study is in agreement with the above works in that insects were more important during the dry season while macrophytes and other invertebrates were more important during the wet season (Admassu and Dadebo, 1997; Dadebo et al., 2013). In general, seasonality did not affect the feeding behavior and the type of prey organisms of $B$. bynni in Lake Abaya because the majority of the food items showed no significant seasonal differences.

\section{Ontogenetic dietary shift}

SDOI revealed no significant variation in the diet of the different size classes because percentage overlap was above $60 \%$ in all combinations of size classes (I and II: 97.2\%; I and III: 75.5\%, I and IV: 62.4\%; II and III: 73.9\%; II and IV: 64.4\%; III and IV: 86.3\%). In general, the contribution of animal origin food was high in the diet of smaller size classes whereas this component declined as the fish grew in size (Figure 3). In fish below $40 \mathrm{~cm} \mathrm{TL}$, insects were important in the diets and the contributions of detritus and macrophytes remained more or less unchanged with size of fish. However, in the diets of $B$. bynni above $40 \mathrm{~cm} \mathrm{TL}$, the fish depended only on detrital matter and macrophytes for its nourishment (Figure 3). Among the minor food items, zooplankton were relatively important in the diet of fish less than $40 \mathrm{~cm}$ TL, but they were absent in the diets of larger fish. Similarly, the significance of phytoplankton, ostracods, gastropods and nematodes was visible in the diets of fish below $40 \mathrm{~cm}$ $\mathrm{TL}$, whereas they were absent in the diets of larger fish (Figure 3).

Ontogenetic diet shift has been shown to occur during the life of many fish species, and prey size is generally positively correlated with fish size (Desta, 2007). A fundamental characteristic of fish is that individuals increase considerably in size, which is usually associated with changes in food resource use (Desta et al., 2006). Based on the results of the present study, slight ontogenetic dietary change was noted. Small fish $(<20$ $\mathrm{cm} \mathrm{TL}$ ) and intermediate size fish (20 to $40 \mathrm{~cm} \mathrm{TL}$ ) predominantly fed on insects, followed by detritus and macrophytes. The composition of the diet of large fish (>40 cm TL) was different from the lower size classes because large fish exclusively fed on only food of plant origin, detritus and macrophytes comprising the total volume of the food categories.

\section{Morphometric relationships}

The relationships between TL and TW of males (11.6 to $35.8 \mathrm{~cm} \mathrm{TL} ; 14.2$ to $359.2 \mathrm{~g} \mathrm{TW}$ ), females (13.4 to 50.0 $\mathrm{cm} \mathrm{TL} ; 15.9$ to $1,200 \mathrm{~g} \mathrm{TW}$ ) and both sexes combined was expressed by the following regression equations:

Males: TW $=0.0033 \mathrm{TL}^{3.277}, \mathrm{R}^{2}=0.989, \mathrm{n}=144, \mathrm{p}<0.001$

Females: $\mathrm{TW}=0.0041 \mathrm{TL}^{3.207}, \mathrm{R}^{2}=0.981, \mathrm{n}=148, \mathrm{p}<0.001$

Combined: TW $=0.0036 \mathrm{TL}^{3.245}, \mathrm{R}^{2}=0.986, \mathrm{n}=292, \mathrm{p}<0.001$

The relationships between $T L$ and $F L(F L=0.866 T L$ $\left.0.316, R^{2}=0.997, n=292, p<0.001\right), T L$ and $S L(S L=$ $\left.0.806 \mathrm{TL}-0.949, R^{2}=0.995, \mathrm{n}=292, \mathrm{p}<0.001\right)$ and $\mathrm{FL}$ and $S L\left(S L=0.929 F L-0.632, R^{2}=0.995, n=292, p<\right.$ $0.001)$ were all linear and statistically significant. As far as our knowledge goes, no study was found on morphometric relationships of $B$. bynni in African water bodies. Admassu and Dadebo (1997) studying a related species (Barbus sp.) in Lake Hawassa found slightly allometric growth pattern with a $b$ value of 3.14

\section{Conclusions}

The food categories consumed by $B$. bynni were, macrophytes, detritus, insects, zooplankton, phytoplankton, ostracods, gastropods, and nematodes suggesting that $B$. bynni are a polyphagous fish species in Lake Abaya. No seasonality in diet was observed, however, there was an ontogenetic change in diet. Smaller size classes $(<19.9 \mathrm{~cm} \mathrm{TL})$ predominantly relied on insects, detritus and macrophytes while medium sized fish (20 to $39.9 \mathrm{~cm} \mathrm{TL}$ ), depended mainly on insects, macrophytes and detritus. On the other hand, larger fish (>40 cm TL) fed only on detritus and macrophytes. The growth pattern of $B$. bynni in Lake Abaya was found to be allometric because the slope of the relationship (b) was 3.25 , which is a value considerably higher than 3 .

\section{Conflict of Interests}

The authors have not declared any conflict of interests. 


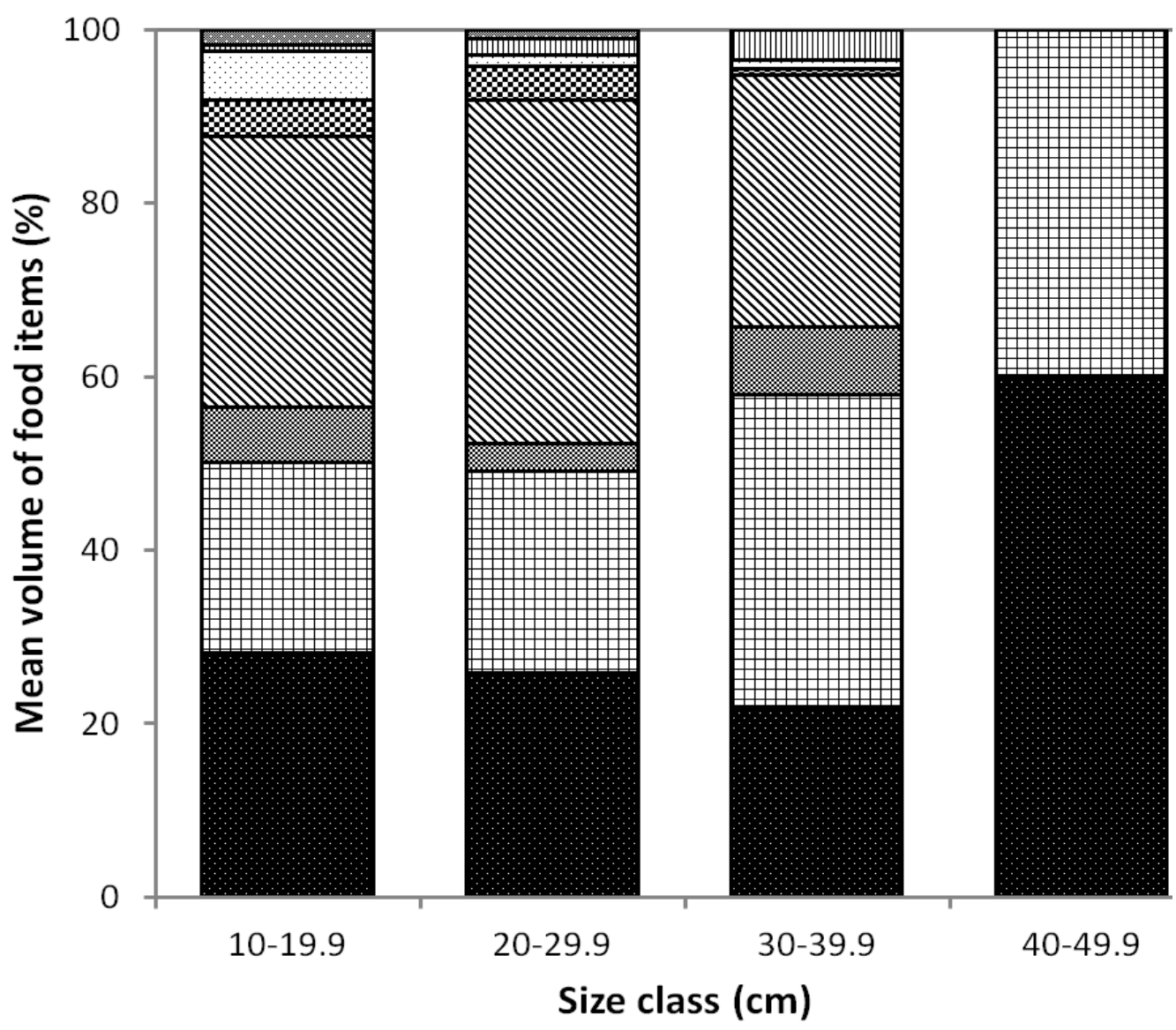

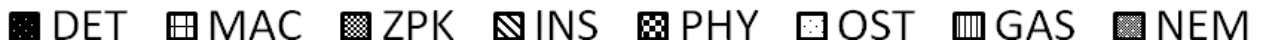

Figure 3. Volumetric contributions (\%) of the different food categories in the diet of different size classes of $B$. bynni in Lake Abaya, as an average for the dry and wet season.

\section{REFERENCES}

Admassu D, Dadebo E (1997). Diet composition, length-weight relationship and condition factor of Barbus sp. (Rüppell, 1836) (Pisces: Cyprinidae) in Lake Hawassa, Ethiopia. SINET: Ethiop. J. Sci. 20(1):13-30.

Appelberg M, Berger HM, Hesthagen T, Kleiven E, Kurkilahti M, Raitaniemi J, Rask M (1995). Development and inter-calibration of methods in Nordic freshwater fish monitoring. Water Air Soil Pollut. 85: 401-406.http://dx.doi.org/10.1007/BF00476862

Bagenal TB, Braum E (1978). Eggs and early life History. In: Methods for assessment of fish production in fresh waters, (Bagenal, T.ed.). Blackwell Scientific Publications, London. pp. 165-201.

Bailey RG (1994). Guide to the fishes of the River Nile in the Republic of the Sudan. J. Nat. Hist. 28(4):937-970. http://dx.doi.org/10.1080/00222939400770501

Banister KE (1973). A revision of the large Barbus (Pisces: Cyprinidae) of East and Central Africa. Studies of African Cyprinidae. Pt. II, Bull. Brit. Mus. Nat. Hist. Zool. 26(1):1-148.

Baxter RM (2002). Lake morphology and chemistry. In: Ethiopian Rift Valley Lakes, (Taylor, W.D and Tudorancea, C., eds). Backhuys Publishers, Leiden.

Beadle LC (1981). The inland waters of tropical Africa. An introduction to tropical limnology, 2nd ed. New York: Longmans, 475 pages.
Berrebi P, Valiushok D (1998). Genetic divergence among morphotypes of Lake Tana (Ethiopia) barbs. Biol. J. Linn. Soc. 64:369384.http://dx.doi.org/10.1111/j.1095-8312.1998.tb00338.x

Bowen SH (1983). Quantitative description of the diet. In: Fisheries Techniques, (Nielsen, L.A and Johnson, D. L. eds). Bethesda, Maryland. pp. 325-336.

De Graaf M (2003). Lake Tana's piscivorous Barbs (Cyprinidae, Ethiopia): Ecology, Evolution, Exploitation. Ph.D. Thesis, Experimental Zoology Group, Wageningen University, $\mathrm{AH}$ Wageningen, the Netherlands.

De Graaf M, van de Weerd GH, Osse JWM, Sibbing FA (2010). Diversification of prey capture techniques among the piscivores in Lake Tana's (Ethiopia) Labeobarbus species flock (Cyprinidae). Afr. Zool. 45(1):32-40. http://dx.doi.org/10.3377/004.045.0117

Dadebo E, Tesfahun A, Teklegiorgis $Y(2013)$. Food and feeding habits of the African big barb Labeobarbus intermedius (Rüppell, 1836) (Pisces: Cyprinidae) in Lake Koka, Ethiopia. E3 J. Agric. Res. Dev. 3(4):49-58.

Desta Z, Borgstrøm R, Rosseland BO, Gebre-Mariam Z (2006). Major difference in mercury concentrations of the African big barb, Barbus intermedius (R.) due to shifts in trophic position. Ecol. Freshwat. Fish. 15:532-543. http://dx.doi.org/10.1111/j.1600-0633.2006.00193.x

Desta $Z$ (2007). Food web structure and mercury transfer patterns in fish community of L. Hawassa, Ethiopia. Ph.D. Thesis. Norwegian 
University of Life Science, Ås.

Desta Z, Borgstrøm R, Gebre-Mariam Z, Rosseland BO (2008). Habitat use and trophic position determine mercury concentration in the straight fin barb Barbus paludinosus, a small fish species in Lake Hawassa, Ethiopia. J. Fish Biol. 73:477-497. http://dx.doi.org/10.1111/j.1095-8649.2008.01920.x

Froese R, Pauly D (2010). List of freshwater fishes of Ethiopia. Fish Base, World Wide Electronic Publications.

Getahun A (2007). An overview of the diversity and conservation status of the Ethiopian freshwater fauna. J. Afrotrop. Zool. Special Issue: pp. 87-96.

Golubtsov AS, Krysanov EV (1993). Karyological study of some cyprinid species from Ethiopia. The ploidy difference between large and small Barbus of Africa. J. Fish. Biol. 42(3):445-455. http://dx.doi.org/10.1111/j.1095-8649.1993.tb00347.x

Golubtsov AS, Darkove AA, Dgebyadze YY, Mina MV (1995). An artificial key to fish species of Gambela region. Joint. Ethio-Rassian Biological Expedition. Artistic Printing Press, Addis Ababa.

Golubtsov AS, Habteselassie R (2010). Fish faunas of the ChamoAbaya and Chew Bahir basins in southern portion of the Ethiopian Rift Valley: origin and prospects for survival. Aquat. Ecosys. Health Manag. 13(1):47-55. http://dx.doi.org/10.1080/14634980903578506

Kolding $J$ (1989). The fish resources of Lake Turkana and their environment. PhD Thesis, Department of Fisheries Biology, University of Bergen, Norway.

Lévêque C, Daget J (1984). Cyprinidae. In: Check-list of the freshwater fishes of Africa (Daget, J., Gosse, J.P. and Thys Vnden Audenaerde, D.F.E, eds). (CLOFFA). Vol.1.ORSTOM, MRAC Tervuren and Paris, France. , pp. 217-342.

Mathur D (1977). Food habits and competitive relationships of Bandfin shiner in Halawakee Creek, Alabama. Am. Midland Nat. 97:89-100. http://dx.doi.org/10.2307/2424687

Nagelkerke LAJ, Sibbing F A, Vanden Boogaart JGM, Lammens EHRR, Osse JWM (1994). The barbs (Barbus Sp.) of Lake Tana: A forgotten species flock? Environ. Biol. Fish 39:1-22. http://dx.doi.org/10.1007/BF00004751
Seegers L, Devose L, Okeyo DO (2003). Annotated checklist of the freshwater fishes of Kenya (excluding the lacustrine haplochromine) from Lake Victoria. J. East Afr. Nat. Hist. 92:11-47. http://dx.doi.org/10.2982/0012-8317(2003)92[11:ACOTFF]2.0.CO;2

Schoener TW (1970). Non-synchronous spatial overlap of lizards in patchy habitats. Ecology 51:408-418. http://dx.doi.org/10.2307/1935376

Schröder R (1984). An attempt to estimate the fish stock and sustainable yield of Lake Ziway and Lake Abaya, Ethiopia Rift valley. Arch. Hydrobiol. (Supp.). 69(3):411-444.

Sokal RR, Rohlf FJ (1995). Biometry: The principles and practices of statistics in biological research 3rd ed. New York, Freeman and Company, P. 859.

Tudorancea C, Gebre-Mariam Z, Dadebo E (1999). Limnology in Ethiopia. In: Limnology in developing countries (Wetzel R.G and Gopel. B. eds). pp. 63-118.

Wallace RK (1981). An assessment of diet-overlap indexes. Trans. Am. Fish. Soc. 110: 72-76. http://dx.doi.org/10.1577/15488659(1981)110<72:AAODI>2.0.CO;2 